wanting in A. chrysantha. The time of flowering is intermediate between that of the two parents; the plants were in full flower by the second half of May. The flowers are much broader than those of A. desertorum, with relatively short spurs (that is, in relation to the breadth), which is not a character of either parent. The sepals are strongly divergent, a character of $A$. chrysantha. The following description is from a characteristic flower.

Flower nodding. Sepals about I9 $\mathrm{mm}$. long and $8 \mathrm{~mm}$. broad, pink, with a faintly purplish shade, or the apex distinctly purplish. Petals $30 \mathrm{~mm}$. long (to end of spur), $8 \mathrm{~mm}$. wide near apex, broadly truncate and sub-marginate apically; apical to $\mathrm{mm}$. cream color, spur rose-pink; spurs much broader basally than in A. desertorum.

Two plants, representing each parent as seed-producer, are essentially alike; but a third, recorded as from $A$. chrysantha pollen on $A$. desertorum, is distinctly different, having longer spurs (petals $34 \mathrm{~mm}$., the truncate apex $7 \mathrm{~mm}$. wide), and longer, narrower sepals (2r mm. long, $6 \mathrm{~mm}$. wide), while the color of the spurs is more purplish, owing to less acidity. It is just possible that this represents A. caerulea pollen on A. desertorum, due to some unobserved insect, although the heads were covered and the records do not indicate any such cross as having purposely been made.

Thus it appears that the color of the flowers and the time of flowering of the $F_{x}$ hybrid are clearly intermediate; but the form of the flowers departs from both parents in the direction of the $A$. vulgaris group. The form of the flower, however, may be given a simple Mendelian interpretation, if we say that the dominant characters are the spur-length of desertorum and the flower-width of chrysantha.

We also have a row of $A$. chrysantha $\times A$. caerulea hybrids, but this form has long been known in gardens. It blooms with $A$. caerulea, and has the flowers paler than $A$. caerulea, with the white replaced by light yellow, which fades to white as the flowers grow old. On the whole, it is nearly $A$. caerulea, with the yellow of $A$. chrysantha superimposed upon it.-T. D. A. Cockerell, Boulder, Colorado.

\title{
AN ALTERNARIA ON SONCHUS
}

(WITH ONE FIGURE)

During recent studies on Alternaria and Macrosporium much material was sent to me by various botanists. Among this was an Alternaria collected by Dr. DAvis near Madison, Wisconsin, which 


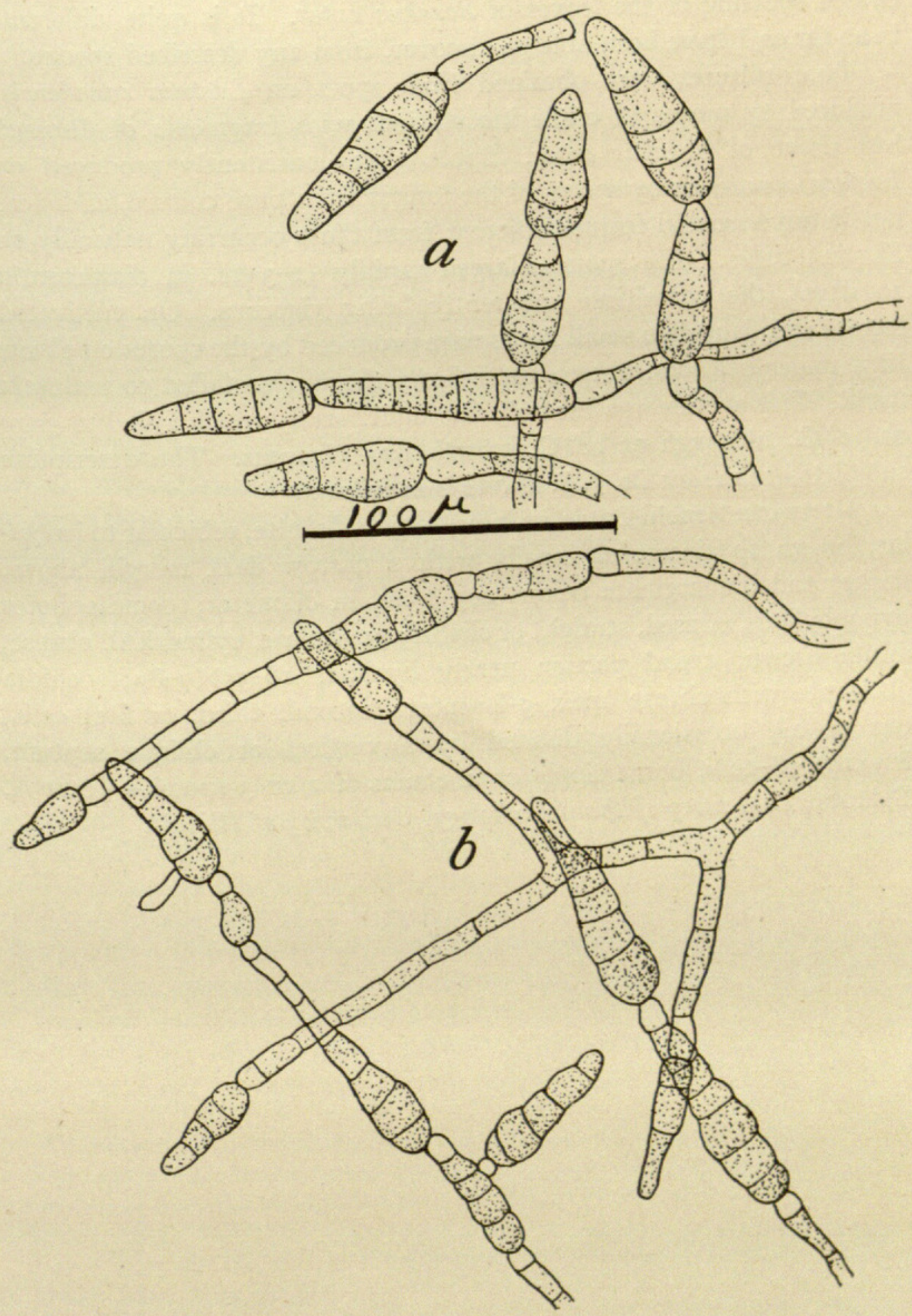

FIG. I 
caused spotting of the leaves of Sonchus asper. It is quite different, in so far as I have been able to discover, from any described species.

Pure cultures were obtained from spots on Lactuca canadensis, produced by means of crude inoculations with fragments of diseased leaf tissue of Sonchus asper. Spots were consistently produced on Lactuca canadensis by spores of the fungus from pure culture, and were not in any essential feature different from those occurring naturally on Sonchus asper. The spots enlarged rapidly $(2-3 \mathrm{~cm}$. in diameter in Io days), the parasitism apparently being vigorous. On cultivated lettuce and dandelion small flecks were produced by the spores on plants kept under bell jars, but on these hosts the fungus failed to maintain itself. This species was the only one under study which failed to grow at $30^{\circ} \mathrm{C}$., although at $20^{\circ} \mathrm{C}$. growth was vigorous. The description submitted to me by Dr. J. J. Davis is as follows:

Alternaria Sonchi Davis, sp. nov.-Spots definite, orbicular to irregular, brown to cinereous, usually with a narrow dark margin above, darker and immarginate below, $0.5^{-1} \mathrm{~cm}$. in diameter; conidiophores hypophyllous, effused, straight or slightly geniculate, cylindrical, obtuse, dilute brown, apical portion nearly hyaline, $18-55 \times 7-8 \mu$; conidia obclavate with obtuse apex, $5^{-8}$-septate, second, third, or first cells, one or all, occasionally divided by a vertical or oblique septum, 80-1 10X $18-20 \mu$, borne singly or in chains of 2 or 3 spores.-JoHN A. Elliotr, Laboratory of Plant Pathology, University of Illinois. 


\section{$2 \mathrm{BHL}$ Biodiversity Heritage Library}

Elliott, John Asbury. 1916. "An Alternaria on Sonchus." Botanical gazette 62(5), 414-416. https://doi.org/10.1086/331952.

View This Item Online: https://www.biodiversitylibrary.org/item/109215

DOI: https://doi.org/10.1086/331952

Permalink: https://www.biodiversitylibrary.org/partpdf/223863

\section{Holding Institution}

Missouri Botanical Garden, Peter H. Raven Library

\section{Sponsored by}

Missouri Botanical Garden

\section{Copyright \& Reuse}

Copyright Status: Public domain. The BHL considers that this work is no longer under copyright protection.

This document was created from content at the Biodiversity Heritage Library, the world's largest open access digital library for biodiversity literature and archives. Visit BHL at https://www.biodiversitylibrary.org. 